Deforming American Political Thought: Ethnicity, Facticity, and Genre

Michael J. Shapiro

University of Kentucky Press, Lexington, KY, 2006, 272pp +xxii.

ISBN: $10081312412-3 / 139780813124123$.

Contemporary Political Theory (2007) 6, 498-500. doi:10.1057/palgrave.cpt.9300314

If Michael J. Shapiro is to be believed, political theorists need to pay attention not only to politics and the political but also to how we think about, the various ways we gain access to, those things we call political. Thus, when we identify politics with electoral matters and party organization, governmental policies, and the canonical texts and ideas of the America tradition, we impoverish rather than advance our thinking about the state of politics and the politics of the state in the United States. In the case of the US, the emphasis upon the 'dominant narrative of nation-building' has overwhelmed 'other modes of affiliation' and obfuscated the 'collage of diverse lifeworlds' (pp. 53-54) that make up the United States, past and present. In the presentation of the story of the American nation as something inevitable as well as desirable, we have neglected - and still do - the 'heteroglassic, polyvalent, diverse set of micropolitical cultures' (p. 63).

As a remedy, Shapiro calls for us to pay attention to cultural materials as diverse as crime fiction, ideas of architecture and landscape, the world of the western, the relationship between classical and vernacular American music and, of course, film. It is through immersing ourselves in the 'lifeworlds' presented in them that we get a better feel for what makes the United States tick or prevent it from ticking. Beyond that, we need to consult other political thinkers than the usual ones. Among Americans, only William Connolly and Sheldon Wolin make the cut, with Judith Shklar in the role of a heavy. Otherwise, it is a congeries of foreign, mostly French, thinkers who provide the roadmaps for negotiating the terrain of contemporary America - Derrida, Rancierre, Deleuze and Guattari with an occasional nod to Tocqueville and Kant. Overall, the goal is to re-present America in the 'subjunctive' rather than the 'declarative' mood (p. 16), to think through alternative ways of thinking about America.

Overall, it is difficult to evaluate Shapiro's book. Individual chapters have lots to recommend them. The chapter on the varieties of American music, focusing not only the tension between vernacular and classical but also upon the contributions of various ethnic and racial groups, is fascinating and stimulating. Shapiro begins by contrasting Tocqueville and Dvorak in the ways each dealt American diversity, with the Frenchman acknowledging but then largely ignoring it, while the Czech composer pioneered the incorporation of 
African American music into the American classical canon. (This was not tokenism on Dvorak's part - he saw African American music as the very foundation of American music.) Surprisingly, Charles Ives was a rigid 'WASP' in these matters. The Jewish and the African American traditions of music Gershwin and Berlin on the one side and Ellington on the other - are contrasted creatively and very interestingly. That said, Shapiro makes almost no room for country music or bluegrass or the various, predominantly 'white' folk traditions. This suggests that in fact 'vernacular' and 'folk' are identified with racial and ethnic minorities. So-called 'white' America comes across as a monolithic culture in these matters.

Nor can Shapiro apparently trust regular political, social and cultural theorists to say anything sensible about the actual diversity of American society, particularly if they are American. One would never know that the original notion of federalism was about both containing and allowing diversity or that it is difficult to speak of an American 'state' until the 20th century. The first half of the 19th century saw a remarkable proliferation of utopian communities all over the new republic. But, any celebration of American variety or of the local or regional must come to terms with the thought and culture of the South, which for 4 years existed as a political nation and for much longer as a cultural entity. Why has it come to be assumed that micropolitics and localism are always on the side of angels? Right wing vigilantes hang-out in the wilds of Montana and Idaho, but 'we' tend not to want to celebrate that kind of different lifeworld.

And where are dissident figures like Randolph Bourne or Paul Goodman, Harold Cruse or Iris Marion Young who sought in various times and ways to think against the established political grain? Goodman and his brother, Percival, wrote a marvellous book back in the late 1940s named Communitas. There they offered just what Shapiro calls for - the exploration of the politics of city and regional planning as it related to the various styles of modern architecture. Shapiro also spends no time with the regional tradition of American thought, by no means a WASP monopoly. Indeed, for all of his insinuations that American political thought is stuck in the same old ruts, he needed to spend more time with that much condemned and neglected mainstream. Is Rawlsian liberalism really hostile to pluralism? Is unitary national sovereignty really that strong a tradition in American political thinking? No one who appreciates Tocqueville, even with all his blind spots, should take cheap shots at Shapiro's use of French thinkers to analyze American social and cultural reality. But in general, American thinkers are probably better guides to the micro-political realities and cultural pluralism of America than the thinkers Shapiro tends to repair to.

Finally, the theoretical weak spot in Shapiro's book is precisely the difficulty he has in moving from the facts of social and cultural diversity, alternative 
lifeworlds and 'counter-memories' (p. 10), to political theoretical alternatives. In stressing the rich diversity of American cultural life, Shapiro rightly reminds us of the inadequacies of many of the old stories about America. Finally, he offers no alternative political ideas or institutions for our consideration.

Richard H King University of Nottingham, Nottingham, UK

\section{Information Please}

Mark Poster

Duke University Press, Durham and London, 2006, 303pp. ISBN: 0822338394.

Contemporary Political Theory (2007) 6, 500-502. doi:10.1057/palgrave.cpt.9300315

Mark Poster's publication of The Mode of Information in 1990 was the start of a major project, still extant, that applied post-structuralism to the study of contemporary media. Though this earlier monograph was a sophisticated critique of the impact of electronic writing on human subjectivity, he could not have envisaged at that time the impact that the World Wide Web (hereafter referred to as 'the Web') would have on Media Studies. And, despite the inevitable alterations in perspective brought about by both the reflexivity that all good scholars should practise and the massive cultural change effected by the Web, Poster's work has succeeded in being consistent without losing the flexibility that is needed to make sense of the vicissitudes of modern western society. His latest book, therefore, explores themes familiar to his readers, such as the role of the media in the construction of subjectivity and the significance to society of the proliferation of information. These and other themes are analysed through the use of a series of interesting case studies. Thus, there are chapters on the use of an image of Sesame Street's Bert alongside Osama Bin Laden's face on banners held by protestors in Bangladesh (pp. 9-26), the Teletubbies as symbolic of the fusion of humans and machines (pp. 176-181), and Philip K. Dick's representation of media and advertising in his novel Ubik (pp. 250-267). These serve to demonstrate respectively the effect on national cultures of the deracination of signifiers from their place of initial reception, the increasing importance of what Poster terms 'humachines' and the potential of science fiction to offer a vision of a posthuman society.

The latter two examples highlight the most fascinating theme of the whole book. Poster has long held the view that developments in media technology over the past 